MINERALOGIA, 42, No 1: 53-61 (2011)

DOI: 10.2478/V10002-011-0006-7

www.Mineralogia.pl

MinERALOGICAL SOCIETY OF POLAND

Polskie ToWARZYSTWO MineRalogICZne

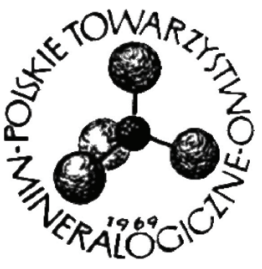

Original paper

\title{
Oxygen isotope analysis of shark teeth phosphates from Bartonian (Eocene) deposits in Mangyshlak peninsula, Kazakhstan
}

\author{
Andrzej PELC ${ }^{1 *}$, Stanisław HAŁAS ${ }^{1}$, Robert NIEDŹWIEDZKI ${ }^{2}$ \\ ${ }^{1}$ Zakład Spektrometrii Mas, Uniwersytet Marii Curie-Skłodowskiej, Pl. M. Curie-Skłodowskiej 1, 20-031 Lublin, \\ Poland; e-mail:andrzej.pelc@umcs.lublin.pl; stanislaw.halas@umcs.lublin.pl \\ 2 Instytut Nauk Geologicznych,Uniwersytet Wrocławski, Pl. Maksa Borna 9, 50-204 Wrocław, Poland; \\ e-mail:rnied@ing.uni.wroc.pl \\ * Corresponding author
}

Received: October 30, 2010

Received in revised form: July 18, 2011

Accepted: March 10, 2012

Available online: March 30, 2012

\begin{abstract}
We report the results of high-precision $( \pm 0.05 \%$ ) oxygen isotope analysis of phosphates in 6 teeth of fossil sharks from the Mangyshlak peninsula. This precision was achieved by the offline preparation of $\mathrm{CO}_{2}$ which was then analyzed on a dual-inlet and triple-collector IRMS. The teeth samples were separated from Middle- and Late Bartonian sediments cropping out in two locations, Usak and Kuilus. Seawater temperatures calculated from the $\delta^{18} \mathrm{O}$ data vary from $23-41^{\circ} \mathrm{C}$. However, these temperatures are probably overestimated due to freshwater inflow. The data point at higher temperature in the Late Bartonian than in the Middle Bartonian and suggest differences in the depth habitats of the shark species studied.
\end{abstract}

Key-words: Bartonian, carbonate, Mangyshlak peninsula, phosphate, shark teeth, $\delta^{18} \mathrm{O}, \delta^{13} \mathrm{C}$

\section{Introduction}

Previous studies on stable isotope analyses of phosphate phases in the teeth of marine vertebrates established that the $\delta^{18} \mathrm{O}$ record has many paleoenvironmental applications (Kolodny, Raab 1988; Vennemann, Hegner 1998; Vennemann et al. 2001; Amiot et al. 
2008; Kocsis et al. 2009). For example, $\delta^{18} \mathrm{O}$ values of modern and fossil teeth and bones reveal information on environmental conditions and climate changes. An especially valuable source of information is the oxygen isotope composition of the phosphate fraction of tooth enamel as it consists of densely packed and relatively large apatite crystals, resulting in a high mineral content of about $96 \%$. In addition, tooth enamel is more resistant to digenetic alterations than, for example, dentine and bone which are $70 \%$ and $60 \%$ mineralized, respectively (Lee-Thorp, Sponheimer 2003).

For the oxygen isotope analyses, a new method involving reduction of silver orthophosphate with graphite was used (Pelc, Halas 2010). Oxygen isotope analyses of fossil shark teeth are rare in the world literature and have not been applied to the remains of Paleogene sharks from the Mangyshlak Peninsula. Based on the stable oxygen isotope analyses of fossil shark teeth, we attempt to reconstruct (i) paleotemperatures of the central part of the Turan Sea during the Bartonian and (ii) the paleoecological preferences of individual shark species.

\section{Geologic setting and sample localities}

The Mangyshlak Peninsula area was located in the central part of the large and shallow Turan Sea, part of the Eastern Paratethys during the Eocene. The Turan Sea was connected with the deep-water Greater Caucasus Basin to the south and with the shallow WestSiberian Basin to the north (Popov et al. 2004). Almost the whole succession of the marine Paleogene is exposed without significant stratigraphic gaps on the Mangyshlak Peninsula. The Paleocene is dominated by limestones. The Ypresian and Lutetian comprise limestones and marls. Marls are the main component of the Bartonian and Priabonian deposits. The Rupelian is represented by calcareous and non-calcareous mudstones and claystones and the Chattian comprises calcareous and non-calcareous claystones (Zhelezko, Kozlov 1999). The Paleogene succession of Mangyshlak has been divided into 14 lithostratigraphic units the informal Danian complex and 13 formations of the Selandian - Chattian succession. The Paleogene deposits of Mangyshlak are generally fossiliferous and contain abundant and diverse shark teeth assemblages, e.g.: Zhelezko and Kozlov (1999) mentioned more than 100 outcrops with shark-bearing layers. Detailed paleontological investigations of shark teeth assemblages have been conducted by Glückman and Zhelezko (1985) and Zhelezko and Kozlov (1999).

The biostratigraphy of the Paleogene deposits of Mangyshlak is based on marine microfossils: planktonic (18 biozones) and benthonic (19 biozones) foraminera, nannoplankton ( 25 biozones), radiolarians (12 biozones) and dinoflagellates (12 biozones) as detailed by Zhelezko and Kozlov (1999). Among Paleogene macrofauna from Mangyshlak, selachian teeth have proved to be the prime tool for biostratigraphy. Resolution of the shark biozonation (20 biozones, see Zhelezko, Kozlov 1999) is comparable to the microfossil zonations noted above. The mass occurrence of diverse and stenohaline fossil organisms indicates favourable environmental conditions and normal seawater salinity during the Paleogene in the Mangyshlak region. Almost all shark genera described by Zhelezko and Kozlov (1999) represent typical marine taxa.

All of the studied shark teeth were collected from two localities in the central- and northern part of the Mangyshlak: the Kuilus outcrop (named Usunbas in some works) and 
the Usak outcrop (Fig. 1). Material from the Kuilus outcrop was found in the lower part of the Middle Bartonian Shorym Formation (lower part of nannoplankton zone NP17 Discoaster saipanensis, planktonic foraminiferal zone Globigerina turcmenica, benthonic foraminiferal zone Brotzenella turkmenica, radiolarian zone Cyrtophormis alta and lower part of the shark zone 12 Otodus poseidoni poseidoni). Teeth from the Usak outcrop were found in marls separating the uppermost part of the Shorym Fm. and the lowermost part of the Aday Fm. (uppermost Bartonian/lowermost Priabonian). The shark assemblage from Usak represents shark zone 13 Otodus poseidoni turanensis (uppermost Bartonian, uppermost Shorym Fm., upper part of the nannoplankton zone NP17, planktonic foraminiferal zone Globigerina instabilis, benthonic foraminiferal zone Bolivina concavasuturata, radiolarian zone Ethmosphaera polysiphonica). The marls of the Kuilus outcrop were deposited during transgression and those of the Usak outcrop during regression. All of the stratigraphical data are as given by Zhelezko and Kozlov (1999 and references therein).

A relatively large island about $120 \mathrm{~km}$ long existed in the northern part of the Mangyshlak Peninsula area during the Paleogene (Zhelezko, Kozlov 1999). Sedimentation in the two collecting sites took place in the nearshore zone of the island. The Usak area was located north of the island and the Kuilus area to the south of the land massif.

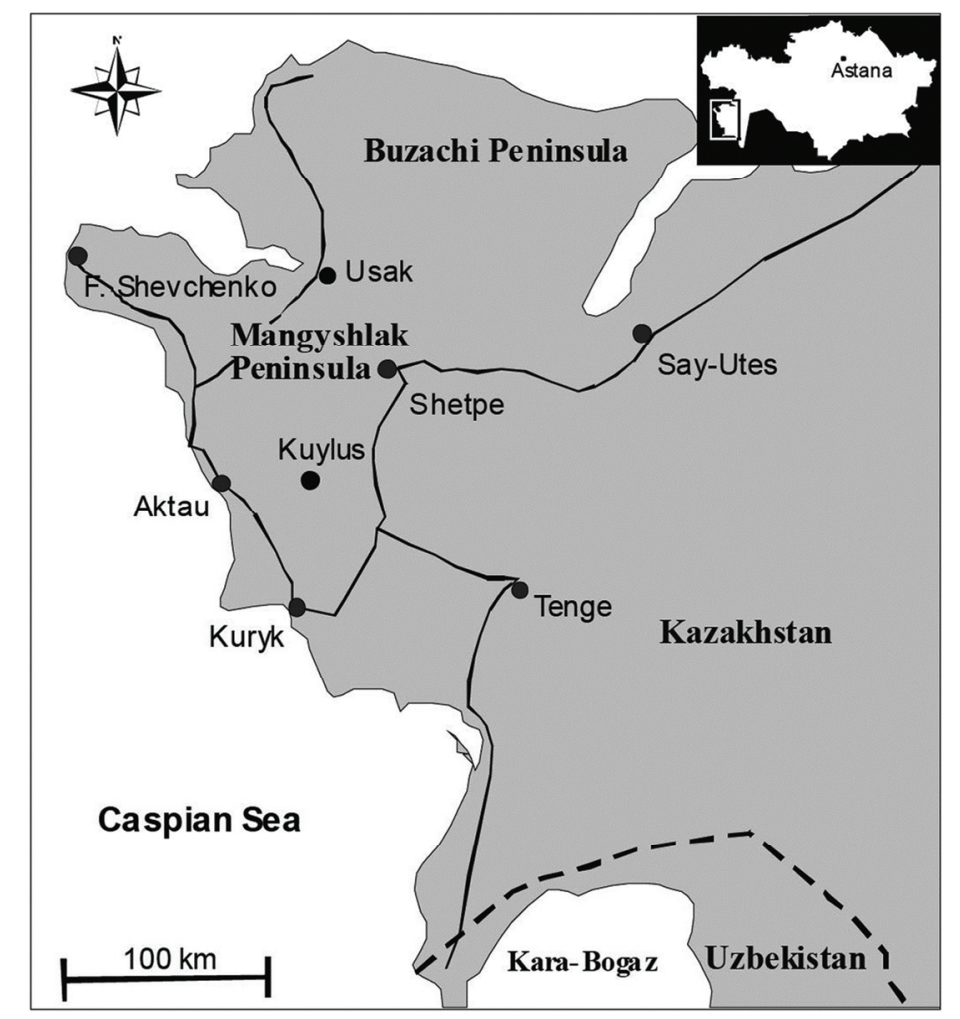

Fig. 1. Geographical setting of the Mangyshlak Peninsula. Solid lines - roads; dashed line - state border; grey circles - towns and villages; black circles - localities of investigated shark teeth. 


\section{Materials}

Two collections of Eocene shark teeth from Mangyshlak were studied by choosing the best preserved material from the collection of the Institute of Geology, Adam Mickiewicz University in Poznań (collected by Prof. Jerzy Liszkowski) and that of the Luhansk Taras Shevchenko National University (collected by Dr. N. I. Udovichenko). From the Udovichenko collection, six shark teeth from adult individuals of three species, namely, Isurolamna bajarunasi (Glückman, Zhelezko (1985), Macrorhizodus americanus (Leriche 1942), both species representing the family Isuridae, and Usakias wardi (Zhelezko, Kozlov 1999) of the family Alopiidae were selected for isotopic analysis. Photographs of the studied teeth are shown in Fig. 2. In general, Isuridae and Alopiidae were pelagic, active swimming sharks though some species of Alopiidae are bathypelagic (Zhelezko, Kozlov 1999; Cappetta 1987). The material selected from both outcrops Usak and Kuilus involves the same three species.
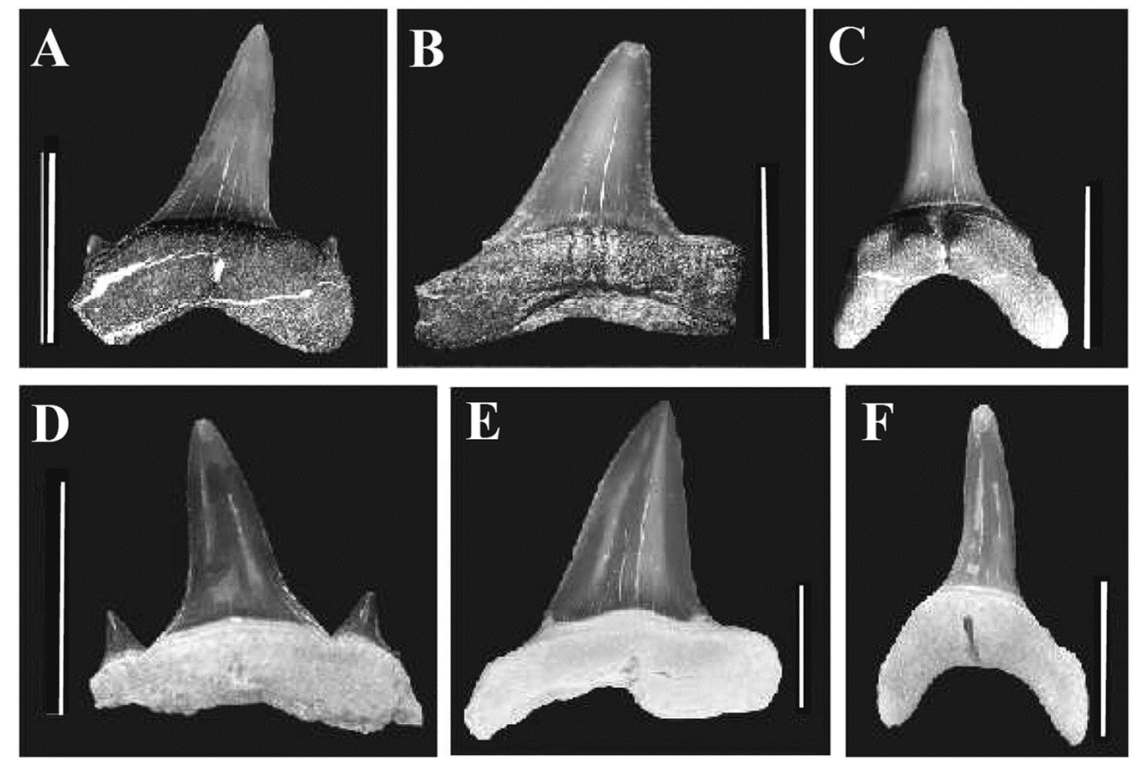

Fig. 2. Studied Bartonian shark teeth from the Mangyshlak Peninsula. A - Isurolamna bajarunasi (Glückman, Zhelezko 1985); B - Macrorhizodus americanus (Leriche 1942); C - Usakias wardi (Zhelezko, Kozlov 1999); D - Isurolamna bajarunasi (Glückman, Zhelezko 1985); E - Macrorhizodus americanus (Leriche 1942); F - Usakias wardi (Zhelezko, Kozlov 1999); Specimens A-C from Usak, D-F from Kuilus. Scale bar $-1 \mathrm{~cm}$.

\section{Experimental}

Prior to analysis, the shark teeth (enamel and dentine) were crushed to powder using a drill. The powder obtained was then carefully crushed again in an agate mortar to remove any residual grains of tooth material. 
In determining the oxygen-isotope composition of the phosphate in the teeth, the protocol of Stephan (2000) was used. The phosphates were converted to silver orthophosphate $\left(\mathrm{Ag}_{3} \mathrm{PO}_{4}\right)$. Extraction of the oxygen from $\mathrm{Ag}_{3} \mathrm{PO}_{4}$ involved the newly invented reduction with graphite method of Pelc and Halas (2010). The preparation line for the graphite reduction of $\mathrm{Ag}_{3} \mathrm{PO}_{4}$ and the subsequent $\mathrm{CO}_{2}$ extraction is similar to that used for oxygen extraction from sulfates. As the preparation line has been described previously in detail (Halas et al. 2007; and Pelc, Halas, 2010), only a brief description is given below.

At the beginning of the test experiments, spectrally pure $\mathrm{Ag}_{3} \mathrm{PO}_{4}$ (Sigma Aldrich, Poznan, Poland) and graphite (Sigma Aldrich, Poznań, Poland) were roasted in a vacuum at $500^{\circ} \mathrm{C}$ and $900^{\circ} \mathrm{C}$, respectively. The $\mathrm{Ag}_{3} \mathrm{PO}_{4}$ and the graphite were then thoroughly mixed in a ratio of 2:1 in an agate mortar.

Aliquots of the mixture weighing about $40 \mathrm{mg}$ were loaded into a platinum boat $(50 \mathrm{~mm}$ long, $5 \mathrm{~mm}$ high and $0.05 \mathrm{~mm}$ thick). The boat with the sample was then introduced into a glass reaction chamber. In the chamber, the boat with the sample was resistively heated. The boat temperature was controlled by the voltage of the power supplied from a variac to a low-voltage transformer connected electrically to the boat. The boat temperatures $(\mathrm{T})$ were estimated with $a \pm 20^{\circ} \mathrm{C}$ uncertainty from the voltages applied by means of a calibration curve which was obtained by pyrometry for $\mathrm{T}>600^{\circ} \mathrm{C}$ and by extrapolation for $\mathrm{T}<600^{\circ} \mathrm{C}$.

To avoid sample spillage, the reaction chamber was slowly evacuated to a pressure below $10^{-3}$ mbar. The sample was then degassed at $200^{\circ} \mathrm{C}$ over about $20 \mathrm{~min}$ in order to remove any volatile impurities. After degassing, the boat temperature was raised gradually to a specific value. Under these conditions, the reduction of silver orthophosphate with graphite took about 30 minutes.

In the reaction, $\mathrm{CO}_{2}$ and $\mathrm{CO}$ gases are produced in amounts depending on the final temperature. $\mathrm{As}_{\mathrm{CO}_{2}}$ gas is more convenient than $\mathrm{CO}$ for mass spectrometric analysis, the $\mathrm{CO}$ fraction was converted to $\mathrm{CO}_{2}$ during the glow discharge between two Pt electrodes installed in the conversion chamber. The $\mathrm{CO}$ to $\mathrm{CO}_{2}$ conversions proceeds in two reaction steps: $\mathrm{CO}$ ionisation

$$
\mathrm{CO}+\mathrm{e} \rightarrow \mathrm{CO}^{+}+\mathrm{e},
$$

and the ion-molecule reaction

$$
\mathrm{CO}^{+}+\mathrm{CO} \rightarrow \mathrm{CO}_{2}+\mathrm{C}^{+}
$$

where $\mathrm{CO}_{2}$ is immediately condensed with liquid nitrogen and $\mathrm{C}^{+}$is discharged at the cathode and remains there. To enhance the efficiency of the ionization process in the conversion chamber, a magnetic field formed by a pair of external neodymium magnets is applied.

The $\mathrm{CO}_{2}$ gas is cryogenically collected on the walls of the conversion chamber immersed in liquid nitrogen. As $\mathrm{CO}$ gas may be trapped in solid $\mathrm{CO}_{2}$, the conversion chamber was heated by a hot gun to sublimate the condensed gases. Then, the $\mathrm{CO}_{2}$ was frozen again, and the released $\mathrm{CO}$ converted to $\mathrm{CO}_{2}$. This procedure was repeated twice before the $\mathrm{CO}_{2}$ collected was cryogenically transferred to the sample ampoule. 
After the $\mathrm{CO}_{2}$ collection was completed, the sample ampoule was connected to the dual inlet system of the isotope ratio mass spectrometer with a triple collector for oxygen isotope analysis.

In a series of step-wise heating experiments for various final (maximum) reaction temperatures, we studied (1) $\mathrm{CO}_{2}$ yield (after conversion of $\mathrm{CO}$ fraction to $\mathrm{CO}_{2}$ in the glow discharge process) and (2) oxygen isotopic composition of $\mathrm{CO}_{2}$. During these studies, the maximum temperature of the sample was varied in the 430 to $830( \pm 20)^{\circ} \mathrm{C}$ range.

Since the oxygen extraction in the graphite reduction of silver orthophosphate is incomplete, the isotope composition obtained has to be corrected by $+0.7 \%$. This correction was precisely determined by analysis of reference standards (NBS-120c, TU-1 and TU- 2) (Halas et al. 2011; Pelc, Halas 2010).

After checking the accuracy and reproducibility of the described method, it was applied to the oxygen isotope determination of the shark teeth phosphates. The commercial $\mathrm{Ag}_{3} \mathrm{PO}_{4}$ was replaced by the silver orthophosphate obtained from the shark teeth. The reduction temperature was adjusted to the optimal value of $750^{\circ} \mathrm{C}$.

\section{Results and Discussion}

The results of the isotopics analyses of the shark teeth are shown in Table 1 . The $\delta^{18} \mathrm{O}$ dataset ranges from 16.63-21.1\% . The teeth from the Kuilus outcrop have higher average $\delta^{18} \mathrm{O}$ values than those from Usak.

TABLE 1

Isotopic composition of oxygen in phosphates in Bartonian shark teeth from the Mangyshlak Peninsula and seawater temperatures derived from the phosphate-water fractionation equations of Longinelli and Nuti (1973) and Pucéat et al. (2010).

\begin{tabular}{llllll}
\hline Outcrop & Age & Shark species & $\begin{array}{l}\delta^{18} \mathrm{O}_{\mathrm{VSMOW}} \\
{[\% \mathrm{o}]}\end{array}$ & $\begin{array}{l}\left.\text { Temperature [ }{ }^{\circ} \mathrm{C}\right] \\
\text { Longinelli and Nuti } \\
(1973)\end{array}$ & $\begin{array}{l}\left.\text { Temperature [ }{ }^{\circ} \mathrm{C}\right] \\
\text { Pucéat et al. (2010) }\end{array}$ \\
\hline Usak & L. Bartonian & I. bajarunasi & 16.63 & 36.5 & 41.3 \\
Usak & L. Bartonian & M. americanus & 18.3 & 29.1 & 34.3 \\
Usak & L. Bartonian & U. wardi & 20.17 & 21.2 & 26.4 \\
Kuilus & M. Bartonian & I. bajarunasi & 20.22 & 21.9 & 27.0 \\
Kuilus & M. Bartonian & M. americanus & 19.85 & 23.5 & 28.6 \\
Kuilus & M. Bartonian & U. wardi & 21.1 & 18 & 23.3 \\
\hline
\end{tabular}

Oxygen isotope fractionation between seawater and marine fish phosphate can be expressed by the following equation (Longinelli, Nuti 1973, Kolodny et al. 1983):

$$
\mathrm{t}=111.4-4.3\left(\delta^{18} \mathrm{O}_{\mathrm{p}}-\delta^{18} \mathrm{O}_{\mathrm{w}}\right)
$$


where $t$ is the temperature of the seawater in ${ }^{\circ} \mathrm{C}, \delta^{18} \mathrm{O}_{\mathrm{p}}$ is the oxygen isotope composition of phosphate and $\delta^{18} \mathrm{O}_{\mathrm{w}}$ is the oxygen isotope composition of seawater. Recently, equation (3) was revised by Pucéat et al. (2010):

$$
\mathrm{t}=118.7-4.22\left(\delta^{18} \mathrm{O}_{\mathrm{p}}-\delta^{18} \mathrm{O}_{\mathrm{w}}+0.9\right)
$$

Lear et al. (2000) estimated the $\delta^{18} \mathrm{O}_{\mathrm{w}}$ values for Cenozoic marine waters. For Middle Bartonian to Latest Bartonian seawater, they obtained $\delta^{18} \mathrm{O}_{\mathrm{w}}$ varying between $-0.6 \%$ (Middle Bartonian) and $-0.8 \%$ (Late Bartonian). The calculated by us high sea-water temperatures ranged from $23-41^{\circ} \mathrm{C}$ (Table 1). These temperatures are not typical of an open, shallow-water, marine environment. The shark teeth are weakly diagenetically altered. Therefore, the most probable explanation for the discrepancy may be that $\delta^{18} \mathrm{O}_{\mathrm{w}}$ in the Turan Sea was lower than in the global ocean. During the Late Eocene, the Eastern Paratethys formed a long but relatively narrow basin surrounded by large land massifs Russian Land to the north, Elburz-Kopetdagh Land to the south, and the Kazakhstan High and Thenshian High to the east (Zhelezko, Kozlov 1999; Popov et al. 2004).

Additionally, the high endemism of Late Eocene fauna in the Turan Sea (Popov et al. 2004) suggests limited exchange of water between the Turan Sea and the global ocean. $\delta^{18} \mathrm{O}_{\mathrm{w}}$ in such partially-isolated sea basins may be much lower than in the open ocean due to freshwater inflow. For example, the modern Baltic Sea water $\delta^{18} \mathrm{O}_{\mathrm{w}}$ attains values as low as $-8.9 \%$ (Fröhlich et al. 1988). Though the influence of the fresh-water input causes overestimation of the calculated absolute water paleotemperatures, nevertheless, the relative temperature gradients between the two studied regions remain correct (see also discussion in Wierzbowski, Rogov 2011). Values of $\delta^{18} \mathrm{O}$ in the teeth phosphate suggest warm (subtropical) waters during both the Middle Bartonian and the Late Bartonian. However, sharks from the Usak locality lived in warmer waters than those from Kuilus.

The trends obtained are consistent with seawater temperature data for the Eastern Paratethys (see Fig. 5 in Zhelezko, Kozlov 1999) where the upper part of the Middle Bartonian and the main interval of the Late Bartonian represent a cooling phase and shortterm warming is visible in the latest Bartonian/earliest Priabonian interval. Because the Mangyshlak region was located in the central part of the Turan Sea (Beniamovski 2007), the warming episode during the latest Bartonian was not a local event and may have been related to the regression and shallowing of the whole basin. The seawater temperature data for the Paleogene of the Eastern Tethys (Zhelezko, Kozlov 1999) are generally consistent with the global oxygen isotope curve for benthic deep-sea foraminifera in the Cenozoic (Zachos et al. 2001). However, the warming episode during the Bartonian/Priabonian interval in Mangyshlak, and mentioned above, is not visible on the global curve. It seems that this was a regional event typical for the Turan Sea as, according to Zachos et al. (2001), there was a long (6 Ma), global period of gradual seawater cooling between 42 and $\sim 36 \mathrm{Ma}$ (latest Lutetian - early Priabonian). The $\delta^{18} \mathrm{O}_{\mathrm{p}}$ values from the Usakias wardi teeth in both the Kuilus and Usak outcrops suggest that this species lived in colder (deeper) waters than did I. bajarunasi and M. americanus which preferred the near-surface layers of the sea. 


\section{Conclusion}

We have demonstrated by the enhanced precision of isotope analysis of shark teeth that a useful insight into the living conditions of sharks can be made on the basis of a rather small number of specimens and, importantly, that seawater temperatures were higher in the Latest Bartonian than those in the Middle Bartonian.

Acknowledgements. We thank Dr. N.I. Udovichenko (Luhansk Taras Shevchenko National University) who donated his specimens for this study. The authors are grateful to anonymous reviewers for their valuable comments and suggestions that improved the quality of the paper. This research was supported by the Institute of Geological Sciences of Wrocław University (grants 2022/W/ING/09-47 and 2253/W/ING/09). The methodological study on phosphates was supported by grant N N307 062136 from the Ministry of Science and Higher Education, Warsaw.

\section{References}

Amiot, R., Göhlich, U.B., Lécuyer, C., Muizon, C., Cappetta, H., Fourel, F., Héran, M-A., \& Martineau, F. (2008). Oxygen isotope compositions of phosphate from Middle Miocene-Early Pliocene marine vertebrates of Peru. Palaeogeography, Palaeoclimatology, Palaeoecology, 264(1-2), 85-92.

Beniamovski, V.N. (2007). The Paleogene straits of northern Eurasia. In E.Y. Baraboshkin (Ed.), The Cretaceous and Paleogene straits of Northern hemisphere (pp. 80-118). Moscow: Geological faculty of Moscow State University. [in Russian].

Cappetta, H. (1987). Chondrichthyes II: Mesozoic and Cenozoic Elasmobranchii. Handbook of Paleoichthyology, 3B. Stuttgart - New York: Gustav Fischer Verlag.

Fröhlich, K., Grabczak, J., \& Rozanski, K. (1988). Deuterium and oxygen-18 in the Baltic Sea. Chemical Geology, $72,77-83$

Glückman, L.S., \& Zhelezko, V.I. (1985). Sharks of the Eocene of Mangyshlak and the boundary of Eocene and Oligocene [in Russian]. Bulletin MOIP. Otdelenie geologicheskoe, 60(5), 86-99.

Halas, S. Szaran, J., Czarnacki, M., \& Tanweer, A. (2007). Refinements in $\mathrm{BaSO}_{4}$ to $\mathrm{CO}_{2}$ preparation and ${ }^{18} \mathrm{O}$ calibration of the sulfate reference materials NBS-127, IAEA SO-5 and IAEA SO-6. Geostandards and Geoanalytical Research, 31, 61-68.

Halas, S., Skrzypek, G., Meier-Augenstein, W., Pelc, A., \& Kemp, H. (2011) Inter-laboratory calibration of new silver orthophosphate comparison materials for stable oxygen isotope analysis of phosphates. Rapid Communications in Mass Spectrometry, 25, 579-584.

Kocsis, L., Vennemann, T.W., Hegner, E., Fontignie, D., \& Tütken, T. (2009). Constraints on Miocene oceanography and climate in the Western and Central Paratethys: O-, Sr-, and Nd-isotope compositions of marine fish and mammal remains. Palaeogeography, Palaeoclimatology, Palaeoecology, 271(1-2), 117-129.

Kolodny, Y., \& Raab, M. (1988). Oxygen isotopes in phosphatic fish remains from Israel; paleothermometry of tropical Cretaceous and Tertiary shelf waters. Palaeogeography, Palaeoclimatology, Palaeoecology, 64(1-2), 59-67.

Kolodny, Y., Luz, B., \& Navon, O. (1983). Oxygen isotope variations in phosphate of biogenic apatites. I. Fish bone apatite - rechecking the rules of the game. Earth and Planetary Science Letters, 64, 398-404.

Lear, C.H., Elderfield, H., \& Wilson, P.A. (2000). Cenozoic Deep-Sea Temperatures and Global Ice Volumes from $\mathrm{Mg} / \mathrm{Ca}$ in Benthic Foraminiferal Calcite. Science, 287(5451), 269-272.

Lee-Thorp, J., \& Sponheimer, M. (2003). Three Case Studies used to Reassess the Reliability of Fossil Bone and Enamel Isotope Signals for Paleodietary studies. Journal of Anthropological Archaeology, 22, 208-216.

Longinelli, A., \& Nuti, S. (1973). Revised phosphate-water isotopic temperature scale. Earth and Planetary Science Letters, 19, 373-376.

Pelc, A., \& Halas, S. (2010). In vacuo reduction of silver orthophosphate with graphite for high precision oxygen isotope analysis. Rapid Communications in Mass Spectrometry, 24, 2827-2830.

Popov, S.V., Shcherba, I.G., \& Stolyarov, A.S. (2004). Map 1: Late Eocene (Priabonian - Beloglinian) 3-6. In S.V Popov, F. Rogl, A.Y. Rozanov, F.F. Steininger, I.G. Shcherba \& M. Kovac (Eds.), LithologicalPaleogeographic maps of Paratethys. Courier Forschungsinstitut Senckenberg, 250, 5-13. 
Pucéat, E., Joachimski, M. M., Bouilloux, A., Monna, F., Bonin, A., Motreuil, S., Morinière, P., Hénard, S., Mourin, J, Dera, G., \& Quesne, D. (2010). Revised phosphate-water fractionation equation reassessing paleotemperatures derived from biogenic apatite. Earth and Planetary Science Letters, 298, 135-142.

Stephan, E. (2000). Oxygen isotope analysis of animal bone phosphate: method refinement, influence of consolidants, and reconstruction of palaeotemperatures for Holocene sites. Journal of Archaeological Science, $27,523-535$.

Vennemann, T., \& Hegner, E. (1998). Oxygen, strontium, and neodymium isotope compositions of fossil shark teeth as a proxy for the palaeoceanography and palaeoclimatology of the Miocene northern Alpine Paratethys. Palaeogeography, Palaeoclimatology, Palaeoecology, 142, 107-121.

Vennemann, T.W., Hegner, E., Cliff, G., \& Benz, G.W. (2001). Isotopic composition of recent shark teeth as a proxy for environmental conditions. Geochimica et Cosmochimica Acta, 65, 1583-1600.

Wierzbowski, H., \& Rogov, M. (2011). Reconstructing the palaeoenvironment of the Middle Russian Sea during the Middle-Late Jurassic transition using stable isotope ratios of cephalopod shells and variations in faunal assemblages. Palaeogeography, Palaeoclimatology, Palaeoecology, 299, 250-264.

Zachos, J., Pagani, M., Sloan, L., Thomas, E., \& Billups, K. (2001). Trends, Rhytms and Aberrations in Global Climate 65 Ma to Present. Science, 292, 686-693.

Zhelezko, W.I., \& Kozlov, W.A. (1999). Elasmobranhii i biostratigrafiia paleogena Zauralia i Sredniei Azii. Ekaterinburg. 